\title{
Awareness, Perception and Satisfaction towards Neera Health Drink: Consumers Perspective
}

\author{
Deepa Chandran and Dr. Philo Francis
}

\begin{abstract}
Health and wellness trend is booming both in Global and Indian markets. As Indian consumers are becoming more and more educated, they are showing more concerns about their health. Neera, an unfermented sweet sap from coconut flowers, is turning out to the latest organic food trend in Kerala. Neera is a delicious health juice containing sugar, vitamins and minerals. As the consumers have so many health drinks choices, Neera will need to fight very hard in order to achieve their share of throats. In this context the present study tries to analyse the customer's attitude towards this innovative product in terms of their awareness, perception and satisfaction. The study is based on simple random sampling method whereby the data is collected from 45 consumers through a comprehensive structured questionnaire. The study also analyses the influence of demographic factors on Neera consumption. Analysis involves descriptive statistics, reliability analysis and various parametric tests. The findings obtained from the study will be useful for Neera manufactures to formulate new marketing strategies or to modify existing drink based on consumers' preference.
\end{abstract}

Keywords--- Awareness, Consumer, Neera, Perception \& Satisfaction.

\section{INTRODUCTION}

$\mathrm{N}$ EERA is a fresh juice and a delicious health drink. It is a sweet non-alcoholic drink. It is an innovative value added product from the coconut processing sector. It can be used as a soft drink as well as health drink which is highly delicious in nature. As it is not fermented chemically, it does not have any alcoholic content and therefore fresh in its form and hence can be consumed by any age group. Therefore, Neera can be termed as 'Keramrith' or 'Sweet Toddy' having taste with lots of benefits.

Neera is a non-alcoholic drink procured form the immature coconut flowers. Production of Neera is very simple as it does not require any mechanical crushing systems, tapping can be done manually by Neera technicians. While Tapping Neera, great care should be given as it will be converted to Toddy once it is fermented. It is collected as a vascular sap from the unopened coconut flowers which is in immature stage, through tapping procedure. For maintaining its fresh form, after tapping it goes through various stages like filtering,

Deepa Chandran, Research Scholar, Research\&PG Department of Commerce, St. Joseph's College, Irinjalakuda, Thrissur, Kerala. E-mail: deepakcc123@gmail.com

Dr. Philo Francis, Retd. Associate Professor, Research Guide, Research\&PG Department of Commerce, St. Joseph's College, Irinjalakuda, Thrissur, Kerala.E-mail:drphilofrancis@gmail.com DOI: 10.9756/BIJIEMS.10463 pasteurizing and preserving using bio-preservatives. Therefore Coconut Development Board has started to conduct workshop for providing training to the Neera technicians. Also this will lead to more employment opportunities in the coconut processing sector.

Neera is considered to be a health drink with lots of medicinal benefits. It helps in digestion and clear urination. Some of the properties of Neera can prevent Jaundice. Even though Neera is enriched with vitamins, minerals and sugars, only a smaller amount amount of sugar is absorbed into blood. Therefore Neera's Glycaemic index is very low. Neera is enriched with Carbohydrates especially sucrose. Its gravity is in between 1.058 and 1.077 and its $\mathrm{pH}$ value is almost neutral. It contains 17 Amino acids, vitamin C, B vitamins, salts, minerals and large amount of protein.

As it an innovative drink in the Indian market, its market potential is unlimited. Neera itself can be promoted and marketed as a healthy delicious soft drink in Indian and international market. Also Neera can be used for the production of various value added products. Coconut flower syrup, jaggery, coconut sugar etc., are some of the value added products from Neera. All these products have high scope in the export market.

At present, the right of granting permission and license for Neera tapping is vested with the Coconut Development Board. Therefore different State Governments of major coconut farming areas have approached $\mathrm{CDB}$ for permission and licensing procedure. In the present situation, CDB is giving license, only to Coconut Producer Societies and Federations in order to protect the small and medium coconut farmers and to ensure better farmer industry linkages in the Indian coconut processing sector.

\section{RESEARCH PROBLEM}

Indian coconut sector was characterised as an oil driven market and hence not as much of progress have been taken place in the area of value addition in the coconut sector. And this has been acting as a hindrance in unleashing its right potential. During this context, the State Governments in major coconut growing states in India in association with Coconut Development Board started to produce and market a delicious health drink from coconut, called Neera. Kerala Government in collaboration with Coconut Development Board is now trying to give more focus on value addition in the coconut processing sector and as a part of this, measures have been taken to promote Neera as an energy drink as well as a sweet beverage which has several nutritional features and vast market potential. Therefore the present study tries to 
determine the Kerala Consumers' awareness, perception and satisfaction regarding Neera health drink and its features.

\section{RESEARCH OBJECTIVES}

1. To explore the awareness of the respondents regarding Neera Drink and its Features.

2. To analyze the perception of the respondents regarding Neera Drink.

3. To evaluate the satisfaction of the respondents towards Neera Drink.

4. To explore the relationship between awareness, perception and satisfaction of the respondents with regard to Neera consumption.

\section{RESEARCH HYPOTHESIS}

1. $\mathrm{HO}_{1}$ : Awareness of respondents regarding Neera drink is equal to average.

2. $\mathrm{HO}_{2}$ : Perception of respondents regarding Neera drink is equal to average.
3. $\mathrm{HO}_{3}$ : Satisfaction of respondents regarding Neera drink is equal to average.

4. $\mathrm{HO}_{4}$ : There does not exists a valid linear regression model between the variables.

5. $\mathrm{H}_{5}$ : Awareness has no causal effect on satisfaction.

6. $\mathrm{HO}_{6}$ : Perception has no causal effect on satisfaction.

\section{RESEARCH MethodOLOGY}

To complete this study primary as well as secondary source of information is used. A structured questionnaire was used to collect data from 45 respondents from Thrissur district. The sampling technique employed for the research purpose was random sampling. For the calculation and analysis of data, statistical tools and techniques like Percentage, Mean, Standard deviation, one sample t test and multiple regression analysis were used with the help of SPSS.21. Cronbach's alpha was used to measure the validity and reliability of the variables under study.

\section{DATA ANALYSIS \& INTERPRETATIONS}

Table 1: Descriptive Statistics of Respondents' Demographic Factors

\begin{tabular}{|l|l|l|l|}
\hline & & Frequency & Percent \\
\hline Gender & Male & 35 & 77.8 \\
\cline { 2 - 4 } & Female & 10 & 22.2 \\
\cline { 2 - 4 } & Total & 45 & 100.0 \\
\hline Age & Below 20 yrs & 5 & 11.1 \\
\cline { 2 - 4 } & $21-40$ yrs & 28 & 62.2 \\
\cline { 2 - 4 } & $41-60$ yrs & 12 & 26.7 \\
\cline { 2 - 4 } & Total & 45 & 100.0 \\
\hline Education & Plus Two & 4 & 8.9 \\
\cline { 2 - 4 } & UG & 9 & 20.0 \\
\cline { 2 - 4 } & PG & 18 & 40.0 \\
\cline { 2 - 4 } & Professional & 14 & 31.1 \\
\cline { 2 - 4 } & Total & 45 & 100.0 \\
\hline Occupation & Student & 3 & 6.7 \\
\cline { 2 - 4 } & Self-Employed & 5 & 11.1 \\
\cline { 2 - 4 } & Govt. Service & 10 & 22.2 \\
\cline { 2 - 4 } & Pvt. Service & 25 & 55.6 \\
\cline { 2 - 4 } & Business & 2 & 4.4 \\
\cline { 2 - 4 } & Total & 45 & 100.0 \\
\hline Monthly Income & $10000-20000$ & 7 & 15.6 \\
\cline { 2 - 4 } & $20000-30000$ & 19 & 42.2 \\
\cline { 2 - 4 } & $30000-40000$ & 12 & 26.7 \\
\cline { 2 - 4 } & $<40000$ & 7 & 100.0 \\
\cline { 2 - 4 } & Total & 45 & \\
\hline
\end{tabular}

Source: Primary Data

The above table shows descriptive statistics of all the demographic variables considered for the study. As per the gender of the respondents, $77.8 \%$ belong to male and only $22.2 \%$ belong to female. As per the age wise distribution, $62.2 \%$ of the respondents are of $21-40$ years of age and $26.7 \%$ of them are of 41- 60 years of age. According to the table, majority of the respondents i.e. $40 \%$ are post graduates and $31.1 \%$ are professionals. It is followed by $20 \%$ of graduates and $8.9 \%$ of having plus two. Among the respondents, majority i. e. $55.6 \%$ belongs to private service sector, followed by $22.2 \%$ in the government service and the rest in other sectors. Monthly income wise classification shows that $42.2 \%$ belongs to $20000-30000$ income group, $26.7 \%$ belongs to 30000 - 40000 income group followed by $15.6 \%$ for both in above 40000 groups and 10000-20000 group each.

\section{Reliability Analysis}

Table 2: Reliability Statistics

\begin{tabular}{|l|l|l|}
\hline & Items & Cronbach's alpha \\
\hline Awareness & 5 & .718 \\
\hline Perception & 5 & .749 \\
\hline Satisfaction & 5 & .702 \\
\hline
\end{tabular}

Source: Primary Data 
The goodness of a measure can be analysed with the help of reliability test which deals with stability and internal consistency among the variables. For that purpose, the Cronbach's alpha has been used in the present study to measure reliability among variables. From the results shown in the table 2 it is clear that, over all, the reliability of all the measures was comfortably placed above 0.70 , ranging from 0.70 to 0.75 . In summary, the instrument used to measure each variable in this study is therefore found to be reliable.

\section{Hypothesis Testing}

$\mathrm{HO}_{1}$ : Awareness of respondents regarding Neera drink is equal to average.

Table 3: One-Sample t Test

\begin{tabular}{|l|l|l|l|l|l|}
\hline & Mean & $\begin{array}{l}\text { Std. } \\
\text { Deviation }\end{array}$ & $\mathrm{t}$ & $\mathrm{df}$ & $\begin{array}{l}\text { p value } \\
\text { Sig.(2-teailed) }\end{array}$ \\
\hline $\begin{array}{l}\text { Average } \\
\text { Awareness }\end{array}$ & 2.5422 & .59180 & -5.189 & 44 & $<0.001^{* *}$ \\
\hline
\end{tabular}

** Significant at $1 \%$ level

Source: Primary Data

Since $\mathrm{p}$ value is less than 0.01 , the null hypothesis is rejected at $1 \%$ significance. Hence conclude that the awareness of respondents regarding the Neera health drink and its features is not equal to the average level. Based on mean score of 2.5422, the opinion regarding the awareness is below average level. As there are no information and advertisements are available in the public media, most of the people are not aware of this innovative health drink.

$\mathrm{HO}_{2}$ : Perception of respondents regarding Neera drink is equal to average.

Table 4: One-Sample t Test

\begin{tabular}{|l|l|l|l|l|l|}
\hline & Mean & $\begin{array}{l}\text { Std. } \\
\text { Deviation }\end{array}$ & $\mathrm{t}$ & df & $\begin{array}{l}\text { p value } \\
\text { Sig. } \\
\text { (2-teailed) }\end{array}$ \\
\hline $\begin{array}{l}\text { Average } \\
\text { Perception }\end{array}$ & 3.111 & .70782 & 1.053 & 44 & .298 \\
\hline
\end{tabular}

Source: Primary Data

Since p value is greater than 0.05 , the null hypothesis is accepted at $5 \%$ significance. Hence conclude that the perception of respondents regarding the Neera health drink and its features is equal to the average level. This is mainly because of the health qualities of coconut and non-alcoholic features of Neera drink, respondents have an average perception regarding Neera.

$\mathrm{HO}_{3}$ : Satisfaction of respondents regarding Neera drink is equal to average.

Table 5: One-Sample t Test

\begin{tabular}{|l|l|l|l|l|l|}
\hline & Mean & $\begin{array}{l}\text { Std. } \\
\text { Deviation }\end{array}$ & $\mathrm{t}$ & $\mathrm{df}$ & $\begin{array}{l}\text { p value } \\
\text { Sig. (2-teailed) }\end{array}$ \\
\hline $\begin{array}{l}\text { Average } \\
\text { Satisfaction }\end{array}$ & 3.45 & .124 & 24.607 & 44 & $<0.001^{* *}$ \\
\hline
\end{tabular}

** Significant at $1 \%$ level

Source: Primary Data
Since p value is less than 0.01 , the null hypothesis is rejected at $1 \%$ significance. Hence conclude that the satisfaction of respondents regarding the Neera health drink and its features is not equal to the average level. Based on mean score of 3.45 , the opinion regarding the satisfaction is above average level. This is mainly because of the health qualities and non-alcoholic features of Neera drink, consumers are more satisfied with the drink than an average.

\section{Regression Model}

Multiple Regression is the analysis used to predict a single dependent variable with the help of more than one independent variables. In multiple regression analysis, $\mathrm{X}$ is considered as independent variables whereby $\mathrm{Y}$ is considered as dependent variable. Simple linear regression can be extended as Multiple Regression. As there will be a number of interrelationships between all the variables, the computational procedures are a bit complex compared to simple linear regression. All the variables and their interrelationship should be measured as per the weights allocated to them in the situation.

In the present study, Linear Regression Model is used with the help of SPSS 21, for exploring and testing the relationship between variables under study. The study considered Satisfaction as dependent variable and Awareness and Perception as independent variables.

Table 6: Model Summary

\begin{tabular}{|l|l|l|l|l|}
\hline Model & $\mathrm{R}$ & $\begin{array}{l}\mathrm{R} \\
\text { Square }\end{array}$ & $\begin{array}{l}\text { Adjusted R } \\
\text { Square }\end{array}$ & $\begin{array}{l}\text { Std. Error of the } \\
\text { Estimate }\end{array}$ \\
\hline 1 & $.978^{\mathrm{a}}$ & .957 & .955 & .12543 \\
\hline \multicolumn{4}{|c|}{ a. Predictors: (Constant), Awareness, Perception } \\
b. Dependent Variable: Satisfaction \\
\hline
\end{tabular}

\section{Source: Primary Data}

The Multiple correlation coefficient denoted by R depicts the relationship between the observed and predicted values. Value of $\mathrm{R}$ lies in between zero and one. The signs of the regression weights indicates the direction of multivariate relationship between the independent variable and dependent variables. The interpretation of $\mathrm{R}$ is the same as to the interpretation of the correlation coefficient, as the value of $\mathrm{R}$ is closer to one, then, linear relationship between the independent and the dependent variable will be greater.

The value of $\mathrm{R}$ can be found in the Model Summary table. In the case of the data, the value for the multiple $\mathrm{R}$ when predicting satisfaction from awareness and perception is .978, a very high value.

$\mathrm{R}^{2}$ or coefficient of determination is computed as the square of multiple correlation coefficient. The interpretation of $\mathrm{R}^{2}$ is similar to $\mathrm{R}$, the proportion of variance in satisfaction that may be predicted by knowing the value of the awareness and perception variables. The $\mathrm{R}^{2}$ value must be greater than 0.60 and here it is 0.957 .

The adjustment in the Adjusted $\mathrm{R}$ Square value in the output tables is a correction for the number of $\mathrm{X}$ variables included in the prediction model.(David W. Stockburger n.d.) Therefore it should be greater than 0.60 and here it shows 0.955 . Adjusted $\mathrm{R}^{2}$ in the results could be reported as $95.5 \%$ 
of the variance in the satisfaction can be predicted by measures of awareness and perception.

The difference between $\mathrm{R}^{2}$ and the Adjusted $\mathrm{R}^{2}$ should be less than $10 \%$. As per the data, the difference is only 0.002 and hence both the values are in line as it doesn't cross the maximum difference level.

The standard error of estimate is 0.12543.it indicates the error of prediction. It can be calculated as an extension of the definitional formula in simple linear regression

Here, all the values are in accordance with the rule, to satisfy a good linear regression relationship between the variables under study and are qualified for entering into a model. Hence, the next step is to identify whether there exist a statistically valid regression model or not. It can be identified from the values shown in the Anova table.

$\mathrm{HO}_{4}$ : There does not exists a valid linear regression model between the variables.

Table 7: ANOVA

\begin{tabular}{|l|r|r|r|c|c|}
\hline Model & $\begin{array}{r}\text { Sum of } \\
\text { Squares }\end{array}$ & df & $\begin{array}{c}\text { Mean } \\
\text { Square }\end{array}$ & F & Sig. \\
\hline Regression & 14.749 & 2 & 7.374 & 468.715 & $<0.001^{* *}$ \\
Residual & .661 & 42 & .016 & & \\
Total & 15.410 & 44 & & & \\
\hline
\end{tabular}

a. Predictors: (Constant), Perception, Awareness

b. Dependent Variable: Satisfaction

** Significant at $1 \%$ level

Source: Primary Data

As on testing hypotheses using regression, the Sum of Squares for the residual, 0.661, is the sum of the squared residuals. The mean square residual, .016, is the squared standard error of estimate. The total sum of squares, 15.410, is the sum of the squared differences between the observed values of satisfaction and the mean of satisfaction. The regression sum of squares, 14.749 , is the sum of squared differences between the model where $\mathrm{Yi}=\mathrm{b} 0$ and $\mathrm{Y}=\mathrm{b} 0+$ $\mathrm{b}_{1} \mathrm{X}_{1}+\mathrm{b}_{2} \mathrm{X}_{2}$.

The regression sum of squares is also the difference between the total sum of squares and the residual sum of squares, $15.410-0.661=14.749$. The regression mean square, 7.374 , is computed by dividing the regression sum of squares by its degrees of freedom. Here it is based on two degrees of freedom because two additional parameters, b1 and b2, were computed.

From the ANOVA table, under the df column, $\mathrm{x} 1=2$, $\mathrm{x} 2=$ $42, X=44$, and $F=468.715$. Since the $p$ value is less than 0.001 at $1 \%$ significance level, implies that, we can reject $\mathrm{HO}_{4}$ in favour of $\mathrm{H}_{1}$. Thus it can be concluded that the Linear Regression Model that has been estimated here between the three variables, is not a mere theoretical construct; actually it does exist and is statistically significant. Hence, the model with variables awareness and perception can significantly predict satisfaction.
As there exist a valid regression model, the next step is to formulate regression equation for the model, which requires the values of beta shown in the Coefficients table.

Table 8: Coefficients

\begin{tabular}{|l|l|l|l|l|l|}
\hline & \multicolumn{2}{|l|}{$\begin{array}{l}\text { Unstandardized } \\
\text { Coefficients }\end{array}$} & $\begin{array}{l}\text { Standardized } \\
\text { Coefficients }\end{array}$ & \multirow{3}{*}{} & \\
\cline { 2 - 5 } Model & B & $\begin{array}{l}\text { Std. } \\
\text { Error }\end{array}$ & Beta & t & Sig. \\
\hline 1(Constant) & 18.422 & .320 & & 57.575 & $<0.001^{* *}$ \\
Awareness & .418 & .096 & 2.002 & 4.346 & $<0.001^{* *}$ \\
Perception & -.416 & .080 & -2.382 & -5.171 & $<0.001^{* *}$ \\
\hline
\end{tabular}

a. Dependent Variable: Satisfaction

** significant at $1 \%$ level

Source: Primary Data

Recalling the prediction equation, $\mathrm{Y}=\mathrm{b} 0+\mathrm{b}_{1} \mathrm{X}_{1}+\mathrm{b}_{2} \mathrm{X}_{2}$, the values for the weights can now be found by observing the "B" column under "Unstandardized Coefficients." They are b0 $=18.422$, b1 $=0.418$, and b2 $=0.416-$, and the regression equation and weights for the sample data appear below.

$$
\begin{gathered}
\mathrm{Y}=18.422+0.418 \mathrm{X}_{1}-0.416 \mathrm{X}_{2} . \\
\mathrm{ZY}=2.002 \mathrm{Z}_{\mathrm{X} 1}-2.382 \mathrm{Z}_{\mathrm{X} 2}
\end{gathered}
$$

For better comparison of regression weights, variables are to be standardized.

Testing for Statistical Significance of $\mathrm{B}_{\mathrm{j}}$

For testing the statistical significance, the maintained hypothesis is that the independent variables like awareness and perception $X_{j}$ has no causal effect on the $Y$. Thus, the null is $B_{j}=0$ (i.e., $X_{j}$ has no causal effect on the $Y$ ) against the alternative that $\mathrm{H}_{1}$ : $\mathrm{B}_{\mathrm{j}}$ is not equal to zero (i.e., $\mathrm{X}_{\mathrm{j}}$ does indeed have some causal effect on the $\mathrm{Y}$; such effect may be direct or indirect. In this case, With respect to awareness and perception, the null hypothesis are as follows:

$\mathrm{H}_{5}$ : Awareness has no causal effect on satisfaction $\left(\mathrm{B}_{1}=0\right)$

Since the $\mathrm{p}$ value is less than 0.01 , with a critical t-value 4.346, $\mathrm{H}_{5}$ must unequivocally be rejected in favour of $\mathbf{H}_{\mathbf{1}}$. Therefore awareness can be said to have a significant influence on satisfaction of the respondents.

\section{$\mathrm{HO}_{6}$ : Perception has no causal effect on satisfaction $\left(\mathrm{B}_{2}=0\right)$}

For perception, since the p value is less than 0.01 with a critical $t$ value $5.171, \mathrm{HO}_{6}$ must be rejected in favour of $\mathrm{H}_{1}$; in which case, perception can be said to have a significant influence on satisfaction of the respondents.

\section{FINDINGS}

1. Based on mean score of 2.5422, the opinion regarding the awareness is below average level. As there are no information and advertisements are available in the public media, most of the people are not aware of this innovative health drink. 
2. The perception of respondents regarding the Neera health drink and its features is equal to the average level.

3. Based on mean score of 3.45 , the opinion regarding the satisfaction is above average level. This is mainly because of the health qualities and non-alcoholic features of Neera drink, consumers are satisfied with the drink more than an average.

4. There exists a statistically significant Linear Regression Model between satisfaction, awareness and perception. Hence, awareness and perception can be said to have a significant influence on satisfaction of the respondents.

5. As per the model, $95.5 \%$ of the variance in the satisfaction can be predicted by measures of awareness and perception.

\section{SUGGESTIONS}

Nowadays changes are happening in the lifestyle of people, which leads to a health conscious society. Therefore, the Government should use appropriate marketing techniques for Neera to compete with other substitute health and energy drinks. Since awareness play a big role in purchase decision making, the government or Coconut Development Board should give more emphasis on providing advertisements in public Medias with a view to make more public awareness about the health and nutritional benefits of Neera.

\section{Limitations OF THE STUDY}

- The study was confined to some areas of Thrissur only according to convenience.

- The study does not take into account the consumption pattern of respondents.

- Chances of some biasness could not be eliminated.

- A small sample size of 45 has been used due to time constraint.

\section{FUtURE RESEARCH IMPLICATIONS}

This is an effort to study the attitude of respondents towards Neera in terms of their awareness, perception and satisfaction. It is a narrow view of the certain aspects. Further research can be conducted on the same area while taking more variables into consideration.

Also the present study does not taken in to consideration the consumption pattern and factors influencing the purchase decision of Neera which will further help to trace out the functional areas such as production, marketing, publicity etc. that need improvements. There is a relevant scope for further studies in that area.

\section{CONCLUSION}

The study concluded respondents' awareness regarding Neera is below average level but their satisfaction is above average level. It shows that the health qualities and non- alcoholic features of Neera drink will make consumers more satisfied with the drink. As there is a lot of ignorance and wrong perceptions regarding Neera energy drink among consumers, the results suggest the need to create awareness regarding the benefits of Neera and correct some wrong perceptions that consumers have. Hence, it is recommended that the Neera marketers should concentrate on improving the quality and brand image of the Neera and at the same time they should concentrate seriously on the sales promotional activities and awareness programmes.

\section{REFERENCES}

[1] R.S. Feldman, "Understanding Psychology: Sensing the World around Us”, Tata McGraw-Hill, 4th Edition, Pp. 89-100, 1997.

[2] L.M. Kathuria and B. Jit, "An Empirical Study of Brand Awareness and the Factors Influencing Brand Loyalty Towards Hair Shampoos”, Brand Management, The Icfai University Press, Vol. 6, Pp.122-132, 2009.

[3] N. Rajaveni and M. Ramasamy, "A Study on Consumer Brand Preference on the Consumption of Cooking Oil of Various Income Groups in Chennai”, Pp. 1-15, 2012.

[4] Gaurav Jaiswal, Dr. Praveen Sahu and Manita Matharu, "Consumer Preferences towards Service Industry: A Factorial Study of Restaurants”, Indian Journal of Marketing, Vol. XXXX, Pp. 35, 2010.

[5] H.P. Singh, "Coconut industry in India- Challenges and opportunities", Indian Coconut Journal , P.14, 1998.

[6] P. Rethinam and Amrizal Idroes, "Global coconut industry-Outlook for the future", Proceedings of the international seminar, Coconut Development Board, 2005.

[7] Minnie Mathew and Thomas Mathew, "The recent fall in copra and coconut oil prices in India”, Indian Coconut Journal, 2007.

[8] P. Rethinam and L. Taufikku Rahman, "Global Coconut Scenario of Coconut Oil”, Indian Coconut Journal, 2002.

[9] Yvonne and T.V Agustin, "Global demand trends and opportunities for marketing and trading in coconut products, Global coconut industry Outlook for the future", Proceedings of the international seminar, Coconut Development Board, Kochi, Pp. 212, 2005

[10] Thomas Mathew, "Economics of marketing of coconut in Kerala”, M. Phil Dissertation, JNU, New Delhi, 1994.

[11] P.K. Jyothsna and D.R. Goodwin, "Brand Evaluation and Purchase Intention”, Brand Management, The Icfai University Press, Vol. 6, Pp.96, 2009.

[12] J. Brug, "Determinants of healthy eating: motivation, abilities and environmental opportunities”, Family Practice, Vol.25, Pp. i50-i55, 2008.

[13] D. A. Aaker, "Measuring brand equity across products and markets", California Management Review, 38(3), 102-120, 1998.

[14] Neera World. (n.d.). Retrieved July 25, 2016, from http://neeraworld. com/about.html

[15] D. Steen and P. R. Ashurst, "Carbonated Soft Drinks: formulation and manufacture. John Wiley \& Sons”. Retrieved from: https://books.google.co.in/books?hl=en\&lr=\&id=LfphGPaZtzwC\&oi=fn $\mathrm{d} \& \mathrm{pg}=$ PR5\&dq=Satisfaction+towards+soft+Drinks\&ots=S82g90wUH\& sig=A04h_qZOH1mspNFp0y0sj14QOBA

[16] D. Goutam, "Influence of Brand Ambassadors on Buying Behavior of Soft Drinks: With Reference to Belgaum City", IMPACT: International Journal of Research in Business Management, Vol.1, No.4, Pp. 9-18, 2013.

[17] D. Ryding, "The impact of new technologies on customer satisfaction and business to business customer relationships: Evidence from the soft drinks industry", Journal of Retailing and Consumer Services, Vol.17, No.3, Pp.224-228, 2010.

[18] L.A. Goodman, "The relationship between modified and usual multipleregression approaches to the analysis of dichotomous variables", Sociological Methodology, Vol.7, Pp. 83-110, 1976.

[19] W. David Stockburger, "Multiple Regression with Two Predictor Variables-Text”, Multivariate Statistics: Concepts, Models, and Applications, http://www.psychstat.missouristate.edu/multibook/ mlt06m.html

[20] Getting a Kick Out of Toddy! Upper Crust", http://www.Upper crustindia.com/14crust/fourteen/ season3.html (August 19, 2016). 